\title{
MOTIVATING FACTORS FOR SUSTAINABLE ACCOUNTANT POTENTIALS IN MALAYSIA
}

\author{
Sharifah Norhafiza Syed Ibrahim*, Nur Farahah Mohd Pauzi, Adriana Shamsudin, Mohd \\ Syazwan Karim, Khairiah Ahmad \\ Faculty of Accountancy, Universiti Teknologi MARA Melaka
}

\begin{abstract}
Economic Transformation Plan (ETP) emphasizes that the country has a pool of resources to steer towards Malaysia's aspirations to become a developed and high-income nation. The ETP Roadmap highlights accountancy, an integral function in all businesses as part of the significant ETP driver. However, Malaysia still lacks the required number of qualified accountants by the year 2020. This challenges higher learning institutions to produce suitable accounting graduates. Despite taking an accounting subject in schools, not all these students later opt to enrol accounting in higher learning institutions as many factors influence their career choices. This study aims to explore these motivating factors. A quantitative approach was applied whereby primary data were collected through a questionnaire survey. Respondents were students from seven elite schools in Melaka. The study found eight motivating factors; family members in the accounting profession, public accountant as a career choice, students' interest in receiving relevant information, choosing private accountants as a career, parents, school counsellor and career talk. However, only four of these factors were significant to students' decisions to pursue professional accounting courses. In addition, parents' influence plays a greater role in motivating students to opt for professional accounting courses as compared to an accounting degree.
\end{abstract}

Keywords: Motivating Factors, Accounting Major, Professional Accounting Programs

\section{INTRODUCTION}

Accountants have a significant role to play in helping to drive Malaysian's economy ahead. They no longer merely responsible to keep the ledger books balanced but they also act as guardians of the 'checks and balances' to ensure the well-being of the company they work for. As Malaysia moves forward to be a developed country by the year 2020, the structure and size of the economy will change, influenced by regional and domestic developments. The private and public sectors will also become more competitive. Such a progression would demand the services of accountants across all sectors. Hence, the availability of talent both in number and with required competencies in various economic sectors would be highly critical.

Accountancy profession in Malaysia is regulated and developed by Malaysian Institute of Accountants (MIA). MIA membership is mandatory for those holding themselves out or practising as an accountant in the country. MIA's membership encompasses both legal and market recognition for accountants in Malaysia. Members of MIA are conferred with the designation of Chartered Accountant Malaysia. This designation is given to those who are professional in accountancy, business, and finance with recognised accountancy qualification and relevant working experiences. As a body for all of the accountants in Malaysia, MIA's responsibilities include education and quality assurance as well as enforcement in order to

*Corresponding author's email: snorhafiza@melaka.uitm.edu.my 
maintain the credibility of the profession and the public interest. The functions of MIA comprise of determining the qualifications for membership admission; providing education and training in accountancy; regulating the practice of accountancy, and promoting the interests of the accountancy profession. At present, there are more than 32,000 MIA members working throughout the states of Malaysia in various industries. Nevertheless, the country is still short about half of the figure whereby Malaysia needs approximately 60,000 qualified accountants by the year 2020 which will be another four more years to go.

The reason for Malaysia being so far behind the required number of accountants is still a questionable mark for everybody. Is that because MIA does not play their role? According to a survey conducted by MIA from the discussion of Committee to Strengthen the Accountancy Profession (CSAP) together with major employers such as Chief Financial Officer (CFO) of commercial banks agreed that among the characteristics to be employed as professional accountants would include qualification as a professional accountants; must have broad skills, not limited to finance and business only; practical and market relevant knowledge; possess soft skill such as management, problem-solving ability, technology savvy; and strong written and spoken communication skills.

Principally, MIA does not have the ability to provide assurance on the baseline competency of its membership. The effectiveness of MIA to enforce compliance with its standards is being questioned. This is important for public confidence and the image of the accountancy profession at large. Employers do not consider MIA as a professional body and only recognise other professional accountancy qualifications such as Malaysian Institute of Certified Public Accountants (MICPA), Association of Certified Chartered Accountants (ACCA), Institute of Chartered Accountants in England and Wales (ICAEW) and Certified Practising Accountant (CPA) Australia which caused limited professional career opportunities for those who do not possess such professional qualifications (CSAP Report, 2014). Besides that, the number of Bumiputera students who possess professional accountancy qualifications is small. Therefore, it is essential for MIA to provide strong leadership in accountancy education and clear competency parameters for training purposes. Certainly, this would enable better alignment between market expectations, professional competencies, and professional accountancy education offered at tertiary levels.

Furthermore, some of our accountancy graduates are lacked in communication skill especially the Bumiputera students. Even though higher education institutions have taken necessary strides to enhance the quality of accountancy graduates, there are still other issues which needed to be addressed. Talent migration is another reason why Malaysia has a small number of professional accountants since it affects the supply of talent in adequate numbers for the needs of the economy. However, Malaysia has a comparative advantage in various industry segments. Therefore, proper planning and follow-up are required to preserve and leverage this advantage.

According to the report done by CSAP in 2014, several actions should be taken by Malaysia in order to sustain the accountancy profession in this country. The recommendations include the introduction of a new regulatory structure which will assist in developing the accountancy profession while promoting public interests through the formulation and enforcement of profession standards; ensuring adequate supply of professional accountants for the economy that fulfils market expectation in terms of knowledge, skills and values; improving the effectiveness and efficiency of the disciplinary structure for the enforcement of professional standards to ensure protection of public interest; ensuring financial support for education, 
research and capacity building for the accountancy profession; creating a conducive and inclusive environment to attract students to pursue professional accountancy profession; fostering support for MIA members to enhance their skills and competency to match the market expectation; strengthening the Small and Medium Practices to render professional services for SMEs; strengthening the accountancy education as well as positioning Malaysia as the hub for accountancy education and training for this region; and enhancing the competitive edge of the profession by developing specialised competencies and skills, for example, in the area of Islamic Finance (CSAP Report, 2014).

\section{Objective of the study}

Approaching ETP portrays Malaysian government is really committed to becoming a high nation income and developed country. One of the detailed ETP roadmaps stated that the role of the qualified accountant is very crucial in executing ETP (Malaysian Institute of Accountant (MIA), 2015). In relation to this roadmap, Malaysian government aims to increase the qualified accountants to 60,000 by the year 2020. According to Wilder \& Stocks (2004), recruiting quality students is a key success to produce professional accountants. The purpose of this study is to explore the motivating factors influencing secondary school students in pursuing the accounting courses. The key way to determine student's career choice is by gaining an understanding of the factors that affect student's career decision (Byrne, Willis, \& Burke, 2012).

Besides, this study put an effort to determine whether there is a significant relationship between all the motivating factors and student's decision to pursue accounting courses. Lastly, this study attempts to suggest programs to inculcate student's interest in accounting courses particularly in professional programs such as ACCA, Chartered Institute of Management Accountants (CIMA), CPA Australia, MICPA and many more.

\section{Problem Statement}

ETP emphasizes that the country has a pool of resources which will steer towards Malaysia's aspirations to become a developed and high-income nation. As highlighted in the ETP Roadmap, accountancy is part of the significant driver and reflects as an integral function in all businesses. In line with the roadmap, MIA was given the big responsibility of developing a sustainable number of competent Chartered Accountants to realise this aspiration. However, based on MIA (2015), the report emphasizes that there is a decline of interest in choosing the accountancy as a preferable profession due to the mentality of long working hours and less glamorous profession as compared to any other professions. According to Sugahara and Boland (2006), the profession becomes unpopular among the brightest business students as they claim that accounting profession to have lower salary compared to other occupation like a consultation or computer-related position.

Over the latest decade, the number of students taking up accounting major has been declined considerably in various part of the world (Zyl \& Villiers (2011), Sugahara \& Boland (2006), Ahmed, Alam \& Alam (1997)). According to Jackling \& Calero (2006), in Australia, there was a drastic increment of students taking undergraduates degrees but the proportion of choosing accounting as a major study has decreased tremendously. Meanwhile, Sugahara, Hiramatsu \& Boland (2009) discovered that the declining numbers of Certified Public Accountants Profession in Japan were mainly due to the requirement in their education 
system of forcing the students to pass a very competitive examination based on technical knowledge and requiring mechanical memorization.

Based on MIA (2015), as at $30^{\text {th }}$ June 2015, the number of professional accountants in Malaysia stands at 31,395 members. 53\% from this number came from local graduates and another $43 \%$ were admitted as members via the professional membership route. In Malaysia, there are fifteen universities offering accounting programmes at undergraduate level such as University of Malaya, Universiti Kebangsaan Malaysia, Universiti Teknologi MARA, Universiti Utara Malaysia, Universiti Putra Malaysia, Universiti Islam Antarabangsa Malaysia, Universiti Sains Malaysia, Universiti Tenaga Nasional, Universiti Multimedia, Universiti Malaysia Terengganu, Universiti Malaysia Sabah, Universiti Industri Selangor, Universiti Sultan Zainal Abidin and Universiti Sains Islam Malaysia. The following table shows the admission of members to MIA from respective universities for the year 2015 and 2014.

Table 1: Admission of members to MIA by local universities

\begin{tabular}{llll}
\hline & Name of University & $\mathbf{2 0 1 5}$ & $\mathbf{2 0 1 4}$ \\
\hline 1 & Bachelor of Accounting, University of Malaya & 49 & 52 \\
2 & Bachelor of Accounting (Honours), University Kebangsaan Malaysia & 44 & 52 \\
3 & Bachelor of Accounting (Honours), Universiti Teknologi MARA & 255 & 219 \\
4 & Bachelor of Accounting (Honours), Universiti Utara Malaysia & 159 & 14 \\
5 & Bachelor of Accounting (Honours), Universiti Putra Malaysia & 61 & - \\
6 & Bachelor of Accounting (Honours), Universiti Islam Antarabangsa Malaysia & 36 & 31 \\
7 & Bachelor of Accounting (Honours), Universiti Sains Malaysia & 32 & 28 \\
8 & Bachelor of Accounting (Honours), Universiti Tenaga Nasional & 26 & 20 \\
9 & Bachelor of Accounting (Honours), Universiti Multimedia & 66 & 49 \\
10 & Bachelor of Accounting (Honours), (Information System) Universiti Utara Malaysia & 28 & - \\
11 & Bachelor of Accounting (Honours), Universiti Malaysia Terengganu & 14 & 14 \\
12 & Bachelor of Accounting (Honours), Universiti Malaysia Sabah & 16 & 17 \\
13 & Bachelor of Accounting (Honours), Universiti Industri Selangor & 16 & 13 \\
14 & Bachelor of Accounting (Honours), Universiti Sultan Zainal Abidin & 1 & - \\
15 & Bachelor of Accounting (Honours), Universiti Sains Islam Malaysia & 5 & - \\
\hline
\end{tabular}

Source: MIA (2015), MIA (2014)

With rapid changes in business environment, it is insufficient for the accounting profession to supply the existing resources to serve the entire business requirement. Therefore, this study was conducted to search for the factors or reasons on why the accounting profession become less favourable among brightest secondary school accounting students.

\section{PRIOR STUDIES}

Several existing studies such as Ahmed \& Alam (1997) and Byrne, Willis \& Burke (2012) which have investigated which factors influence students' decision to choose accounting find rewards and job satisfaction are a few of the significant motivating factors. However, most of these studies conducted surveys among tertiary students. Nevertheless, students who aspire to become accountant are more likely have decided so as early as when they are in schools (Byrne, Willis and Burke (2012). Byrne, Willis \& Burke (2012) also found that accounting teachers do not influence this decision. Hence, awareness programs such as career talks and seminars should provide as much information as possible so that school students are more inclined to pursue accounting studies (Byrne, Willis \& Burke, 2012) and consequently, to work as professionally qualified accountants. This study reviewed prior research related to the five aspects of factors that motivate students' decisions to pursue an accounting degree 
and professional accounting courses. These factors were categorised into five themes; awareness, family, interest, career choice and rewards. They were later constructed in the questionnaires.

\section{Awareness}

To date, Malaysia is still far behind the target of producing 60,000 qualified accountants by the year 2020. Concerns have been raised in the past few years about the shortage of qualified accountants by many sectors. Apparently, the shortage of qualified accountants could be due to less exposure been made to students as early as secondary school level. According to MIA (2014), none of the career and awareness talks has been conducted for secondary schools from July 2013 until Jun 2014. But, MIA (2015) showed an improvement with one session of the career and awareness talk has been conducted for secondary schools. Therefore, in order to attract more accounting graduates, necessary exposure effort should be conducted at early stage possible so as to attract potential students.

Nowadays, higher learning education has become a priority to students after they had completed their high school education. According to Blackwell \& Pinder (2014), students' decision to attend college is encouraged by an inner drive to achieve a better way of life and not influenced by their family. In fact, students begin to make their career choices in their childhood and were fixed by the time they completed their school education (Smyth \& Hannan, 2000; Jackman \& Hollingworth, 2005). Therefore, it is essential to give exposure to students regarding the choices they would have to pursue their study in a higher learning institution so that they can make the right decision to choose the pathway in order to achieve their dream.

Apart from that, the decision made by the students either to pursue their education in accounting field or not would also depend on their perception towards the accounting course itself as well as their performance during high school level. It is believed that the students might be affected by the perceived difficulty of the accounting course (Allen, 2004) and ultimately discouraged them from pursuing studies in the accounting field. Furthermore, exposure to the accounting profession could adversely affect students' perception and career aspiration (Marriott \& Marriott, 2003). Hence, students should be exposed to various sources to acquire information about future profession and career opportunities in order to make any considerations from the valid bases and be prepared for the future undertakings.

\section{Family}

Empirical evidence regarding the influence from different reference group such as parents, friends, teachers, and career advisors on students' choice of an accounting discipline is inconclusive. Results of the study done by Balckwell \& Pinder (2013) revealed that the firstgeneration college students, unlike the third-generation college were not encouraged by family to attend college but their inner drive to attend college to achieve a better way of life for themselves led them being the first in their families to attend and graduate from college. First-generation students in this study referred to respondents' age between 53 to 72 years old meanwhile the third-generation students referred to respondents' age between 41 to 52 years old.

According to Dalci, Arasli, Tumer, \& Baradani (2013), referents (parents, teachers, career advisors and peers) were significantly associated with Iranian student's decision to major in 
accounting. The results also indicated that Iranian students were sensitive to referents' opinions in choosing an accounting major. This finding might be due to the fact that people were closely knitted to each other and they as a group must be considered before individuals within the Islamic society. Additionally, civil and external wars have increased the importance of hierarchical order in Iran. Thus, it was surprising that Iranian students attached profound importance on opinions of the referent group such as their parents. Moreover, the findings of Paolillo \& Estes (1982), Mauldin, Crain \& Mounce (2000) and Geiger \& Ogilby (2000) revealed that in the USA instructors have a profound influence on students' decision to major in accounting. However, Gul, Andrew, Leong \& Ismail (1989) found a contradict findings in Australia whereby parents did not play a significant role in students' choice of majors.

\section{Interest}

Being a qualified accountant requires some strong personal traits such as dedication, commitment, and passion for knowledge and self-enhancement. Thus, individuals with such traits are more likely to succeed in becoming a qualified accountant. Prior studies investigated whether positive attitude towards accounting influence students' decisions to major in accounting and to pursue accountant as a career. Using the theory of reasoned action (TRA) to assess intentions and behaviours in employment choice, levels of interest in accounting and attitudes towards the work of accountants between Australian and international students' differ significantly (Jackling \& Calero, 2006). They further identified the positive impact of government policy on motivating international students towards accounting and the accounting profession. In addition, earlier exposure to accounting in schools as compared to non-accounting and non-business subjects may influence students' interest to pursue accounting majors (Sugahara, Hiramatsu, \& Boland, 2009).

A study on commerce students in Australia to examine both the accounting education decision and the decision to pursue and remain in an accounting career by using a logistic regression model incorporating demographic and academic factors, as well as students' perceptions of the work of accountants, to predict intention to become an accountant indicated that the three significant factor influencing intention to work as an accountant were the perception of importance of generic skills, intrinsic interest in the discipline area, and course satisfaction (Jackling \& Calero, 2006). However, a study on Iranian students did not find a genuine interest in accounting, perception of the accounting course, and perception of the accounting profession significant in influencing students' decision to study accounting (Dalci et al., 2013).

As the type of students changes over time, some factors such as intrinsic factors such as personal interest might not be significant motivating factors in the late $90 \mathrm{~s}$ as found by Ahmed and Alam (1997) but were significant in the recent study such as found by Byrne, Willis and Burke (2012). Hence, new studies may reveal new significant motivating factors as well as some contradicting factors.

\section{Career Goal}

Jackling \& Calero (2006) investigated on students' perception of accountants' work with their intention to become an accountant. There was a strong support when the student perceived generic skills such as the ability to work in a teamwork, soft skills and writing skills were important, they intend to pursue an accounting career compared to those students 
who do not perceive these skills are important. The bad image of accountants that has been shown in television or film will not influence on career decisions, particularly of first-year university students. This is also supported by Sugahara, Hiramatsu \& Boland (2009) who found that the decisions on career choice of Japanese students were not also be influenced by negative images of the certified Public Accountant profession. Meanwhile, Sugahara and Boland (2006) found that those students who were looking for necessary skills were more likely to choose an accounting profession as their chosen career path as they believed that the profession will have good future prospects, advancement opportunities, and powerful authority.

In addition, Sugahara and Boland (2006) also investigated the relationship between job market condition and students' career choice whereby job market condition refers to job availability, job security, job variety and adventure as well as flexibility in career option. The results discovered that job availability and job security was perceived to have a higher influence on students' career decision. The career is believed to be a stable profession in terms of employability. The is supported by Cilliers \& Charl (2011) who revealed that students' career choice was influenced mainly by job security, job satisfaction, and potential future earnings. Moreover, Byrne, Willis \& Burke (2012) also found that the students' career choice was mainly driven by job satisfaction, good working condition, and career aptitude. Furthermore, Dalci et al., (2013) investigated the factor of career option among Iranian students which revealed that the relationship between job market factors has a significant relation to career choice decision. This finding could be attributed to the war, high inflation rates, foreign embargos, and high unemployment rates in Iran since the students were more likely of looking forward to financial and job market issues when choosing a career under such conditions.

Additionally, Law (2010) discovered that flexibility of career options has the significant influence on the likelihood of accounting students to choose general accounting career rather than a non-accounting career. Non-accounting students from business, psychology, and education all agreed that the supply of jobs in accounting is better than any other field. Notably, students who have the intention to pursue careers in audit field perceived that they would have more client interaction, better future job opportunities, greater knowledge of the whole business process. In addition, students who aimed to pursue careers in tax field were looking forward to more stable daily routine, developing more specialised skill and building a more collaborative relationship with clients (Dalton, Buchheit \& McMillan, 2014).

\section{Rewards}

Abraham Maslow is prominent with his theory of human motivation in 1943. Maslow proposed five basic needs in describing the stages of human growth arranging from lower to the higher stage for physiological, safety, love, esteem and self-actualization. Based on Maslow's theory, self-esteem needs can be met by rewarding or appreciating people for their efforts (Maslow, 1943). This sort of esteem is important to encourage people to develop themselves to become a better person. Moreover, self-esteem portrayed that all humans having a need to feel respected, accepted and valued by others. Some people incline to engage in a profession for the purpose of gaining recognition and subsequently, being recognized. Based on that theory, typically students may tend to pursue their study at the university level or professional level for the recognition and to get financial incentive from their employment. 
Plenty of prior researchers revealed that high salary was one of the factors influencing student's career decision (Ahmed, Alam, \& Alam, 1997; Felton, Dimnik, \& Northey, 1995; Hermanson, Dana \& Hermanson, Roger, 1995; Lowe \& Simons, 1997; Tan \& Laswad, 2006). According to Carpenter \& Foster (1977), there was a three-dimensional model of factors influencing student's career decision, namely, intrinsic factor (intellectual interest, job satisfaction), extrinsic factor (availability of employment, remuneration) and interpersonal factor (influence of others such parent and siblings). However, the findings of majority researchers were inconsistent with the Carpenter \& Foster's model in describing factors influencing student's career decision such as Felton, Buhr, \& Northey, (1994); Lowe \& Simons (1997) and Paolillo \& Estes (1982).

The early study in exploring factors influencing student's career decision, to begin with, Paolillo \& Estes (1982) who ranked potential earning earned by employment as one of the most important factors. Subsequently, many researchers found that financial reward or potential earnings have highly significant relationship in influencing student's decision in choosing a career in accounting (Cohen \& Hanno, 1993; Felton et al., 1994; Gul, Andrew, Leong, \& Ismail, 1989; Nelson, Vendrzyk, Quirin, \& Allen, 2002). Overall, the findings from previous studies indicated that students were motivated by financial reward, high salary or potential earnings to choose accounting as their career.

\section{RESEARCH DESIGN AND DATA COLLECTION}

A quantitative approach was applied whereby primary data were collected through the questionnaire survey from which the numbers were used to indicate the motivation factors that might influence the students to pursue their education in accounting particularly professional accounting courses. According to Soni \& Kodali (2012), the most highly preferred data collection method for survey research is questionnaire as compared to interview or combination of other types of data collection method as it could provide a much more valid measure (Ulmer \& Wilson, 2003).

The questionnaire were constructed based on the motivating factors suggested by prior studies. It consisted of ten questions covering gender, school and two questions on decisions to major in accounting and to pursue professional accounting programs as well as six questions on the factors influencing these decisions. The six questions were related to awareness, family background, attitude, career plan, and rewards. Answers to these questions provide thirteen motivating factors as summarised in Table 2 below. Following Agarwala (2008), these factors were grouped into three types; intrinsic factors, extrinsic factors, and interpersonal factors. Intrinsic motivation reflects the natural human propensity to learn and assimilate whereas extrinsic motivation was argued to reflect external control (Ryan \& Deci, 2000). Interpersonal factors were influenced by the perceptions, attitudes, and expectations of others such as parents and friends (Agarwala, 2008). Unlike existing studies which require the respondents to rate the factors using a Likert-scale, this study asks respondents to choose the factors that they think influence them either to pursue accounting major or to pursue any professional accounting qualification. 
Table 2: Motivating Factors to Pursue Accounting and Professional Accounting Qualifications

\begin{tabular}{|c|c|c|}
\hline Intrinsic factors & Extrinsic factors & Interpersonal factors \\
\hline Enthusiasm or & 1. Perceived interest of & 1. Exposure from career talks and \\
\hline $\begin{array}{l}\text { Eagerness for related } \\
\text { information }\end{array}$ & $\begin{array}{l}\text { accounting students } \\
\text { Perceived interest of }\end{array}$ & $\begin{array}{ll} & \text { seminars } \\
\text { 2. Friends' influence }\end{array}$ \\
\hline 2. Career choice - & $\begin{array}{l}\text { accountants, } \\
\text { Monetary rewards earned by }\end{array}$ & 3. School counsellor influence \\
\hline $\begin{array}{l}\text { 3. Career choice - } \\
\text { private accountant }\end{array}$ & 3. Good image of accountants & $\begin{array}{l}\text { 5. Family members are accounting } \\
\text { graduates }\end{array}$ \\
\hline Career choice - other & $\begin{array}{l}\text { Skills and experience gained } \\
\text { by accountants }\end{array}$ & $\begin{array}{l}\text { 6. Family members work as accountants } \\
\text { or/and auditors }\end{array}$ \\
\hline
\end{tabular}

As for this study, the data was collected from the program known as 'Kelestarian Program Perakaunan' (KPP) which was held on 21 March 2016 at Auditorium Hall, Universiti Teknologi MARA, Jasin Campus. This program was attended by a total of 233 form five students from seven elite schools around Melaka who will be taking an accounting subject for their 'Sijil Pelajaran Malaysia' (SPM) examination in November 2016. The schools involved were Maktab Rendah Sains MARA Alor Gajah, Maktab Rendah Sains MARA Tun Ghafar Baba, Maktab Rendah Sains MARA Terendak, Sekolah Menengah Kebangsaan Tinggi Perempuan Melaka, Sekolah Menengah Kebangsaan (A) Sharifah Rodziah, Sekolah Menengah Kebangsaan (A) Sultan Muhammad and Sekolah Menengah Kebangsaan (A) Tun Perak.

KPP program is planned to be implemented for five consecutive years. It started in the year 2015 and 2016 was the second year the program was conducted. The program intends to give exposure to students regarding the accounting field particularly to an emphasis on the professional accounting courses as their preliminary information as a guide in choosing their track to pursue studies in higher learning institution so that the ultimate aim to become a qualified accountant is achievable within stipulated time period.

KPP program has been run for one full day starting from 8 am until $5 \mathrm{pm}$. The program consisted of four slots, namely, briefing regarding 'UiTM Di Hatiku' by Deputy Rector of the Academic Affairs, briefing on the accounting courses offered by UiTM Melaka by the faculty coordinator, briefing on the professional accounting courses such as Certified Accounting Technician (CAT), Certificate of Business Accounting (CBA), Association of Certified Chartered Accountants (UK) (ACCA) and Chartered Institute of Management Accountants (CIMA) by senior lecturer, Centre of Professional Accountancy (IPAC) Education, Shah Alam and the final and awaiting slot was 'The Great Journey' forum whereby three alumni of UiTM professional accounting courses from various backgrounds have been invited to share their experiences and tips while studying the professional accounting courses with all the students.

\section{RESULTS AND FINDINGS}

Table 3 shows descriptive statistics of the data. The largest group was from SMKA Sharifah Rodziah where all students have decided to pursue accounting course. 
Table 3: Group Size by Gender and Schools

\begin{tabular}{lrrr}
\hline School Name & Male & Female & Total \\
\hline MRSM Tun Ghafar Baba & 13 & 10 & 23 \\
MRSM Terendak & 11 & 23 & 34 \\
SMKA Sh Rodziah & 0 & 32 & 32 \\
SMKA Sultan Mohamad & 27 & 0 & 27 \\
SMK Tinggi Perempuan Melaka & 0 & 36 & 36 \\
SMKA Tun Perak & 8 & 17 & 25 \\
\hline TOTAL & 59 & 118 & 177 \\
\hline
\end{tabular}

Table 4 summarises the number of students who decided to major in accounting by gender and school. Approximately $8 \%$ of the respondents did not intend to study accounting in their tertiary education, $25 \%$ of them had not decided yet and $67 \%$ decided to major in accounting. As the majority of the participants and hence the respondents were female, the number of female students who decided to choose accounting course was about $70 \%$, which was doubled the number of male students.

Table 4: Group Size and Decisions on Majoring Accounting by Schools

\begin{tabular}{lrrr}
\hline Decision & Male & Female & Total \\
\hline No MRSM Tun Ghafar Baba & 1 & 2 & 3 \\
MRSM Terendak & 2 & 0 & 2 \\
$\quad$ SMK Tinggi Perempuan Melaka & 0 & 9 & 9 \\
TOTAL & 3 & 11 & 14 \\
Not sure yet & & & \\
$\quad$ MRSM Tun Ghafar Baba & 4 & 2 & 6 \\
MRSM Terendak & 2 & 4 & 6 \\
SMKA Sh Rodziah & 0 & 5 & 5 \\
SMKA Sultan Mohamad & 11 & 0 & 11 \\
SMK Tinggi Perempuan Melaka & 0 & 9 & 9 \\
$\quad$ SMKA Tun Perak & 3 & 4 & 7 \\
TOTAL & 20 & 24 & 44 \\
Yes & & & \\
$\quad$ MRSM Tun Ghafar Baba & 8 & 6 & 14 \\
MRSM Terendak & 7 & 19 & 26 \\
SMKA Sh Rodziah & 0 & 27 & 27 \\
SMKA Sultan Mohamad & 16 & 0 & 16 \\
SMK Tinggi Perempuan Melaka & 0 & 18 & 18 \\
$\quad$ SMKA Tun Perak & 5 & 13 & 18 \\
\hline TOTAL & 36 & 83 & 119 \\
\hline
\end{tabular}

Results for a decision on pursuing professional accounting qualification are summarised in Table 5. Interestingly, the number of respondents who intend to pursue professional accounting qualification is higher than those of pursuing accounting major which is approximately $84 \%$ of the respondents. Indirectly, this may indicate there are some students who have decided to directly enrol for professional accounting program after SPM. Both the number of male and female students who are interested in studying for professional accounting courses were greater compared to those of pursuing an accounting degree. This may also indicate that being professionally qualified accountants is more appealing to this group of students. Since the questionnaires were completed after the KPP program had ended, these results showed that the program was successfully influencing students to opt professionally qualified accountants as their future careers. 
Table 5: Group Size and Decisions on Taking Professional Accounting Course by Schools

\begin{tabular}{lrrr}
\hline Decision & Male & Female & Total \\
\hline No $\quad$ MRSM Tun Ghafar Baba & 1 & 2 & 3 \\
MRSM Terendak & 0 & 1 & 1 \\
SMKA Sh Rodziah & 0 & 1 & 1 \\
SMKA Sultan Mohamad & 2 & 0 & 2 \\
$\quad$ SMK Tinggi Perempuan Melaka & 0 & 8 & 8 \\
$\quad$ SMKA Tun Perak & 1 & 0 & 0 \\
TOTAL & 4 & 12 & 15 \\
Not sure yet & & & \\
$\quad$ MRSM Tun Ghafar Baba & 2 & 0 & 2 \\
MRSM Terendak & 0 & 3 & 3 \\
$\quad$ SMKA Sh Rodziah & 0 & 1 & 1 \\
SMKA Sultan Mohamad & 2 & 0 & 2 \\
$\quad$ SMK Tinggi Perempuan Melaka & 0 & 4 & 2 \\
$\quad$ SMKA Tun Perak & 0 & 1 & 4 \\
TOTAL & 4 & 9 & 13 \\
Yes & & & \\
$\quad$ MRSM Tun Ghafar Baba & 10 & 8 & 18 \\
$\quad$ MRSM Terendak & 11 & 19 & 30 \\
SMKA Sh Rodziah & 0 & 30 & 30 \\
SMKA Sultan Mohamad & 23 & 0 & 23 \\
SMK Tinggi Perempuan Melaka & 0 & 24 & 24 \\
SMKA Tun Perak & 7 & 16 & 23 \\
\hline TOTAL & 51 & 97 & 148 \\
\hline
\end{tabular}

The following table shows which factors are significantly correlated to students' decisions to pursue accounting major and to pursue professional accounting qualifications. The data were both correlated by parametric and non-parametric correlations. Both results were consistent. The results shown were based on a non-parametric analysis which was slightly lower both in coefficients and statistical powers than those from parametric analyses.

Table 6: Factors with Significant Relation (Spearman's rho correlation)

\begin{tabular}{lll}
\hline Factors & Pursue Accounting Major & $\begin{array}{l}\text { Pursue Professional Accounting } \\
\text { Qualifications }\end{array}$ \\
\hline $\begin{array}{l}\text { 1.Pursue Accounting Major } \\
\text { 2.Exposure from career talks and seminars }\end{array}$ & $0.125(\mathrm{p}=0.098)^{*}$ & $0.319(\mathrm{p}=0.000)^{* * *}$ \\
3.Parents' influence & $0.142(\mathrm{p}=0.059)^{*}$ & $0.155(\mathrm{p}=0.040)^{*}$ \\
4.School counsellor influence & $0.142(\mathrm{p}=0.060)^{*}$ & \\
5.Family members work as accountants & $0.683(\mathrm{p}=0.000)^{* * *}$ & $0.379(\mathrm{p}=0.000)^{* * *}$ \\
or/and auditors & $0.206(\mathrm{p}=0.006)^{* * *}$ & \\
6.Eagerness for related information & $0.248(\mathrm{p}=0.001)^{* * *}$ & $0.230(\mathrm{p}=0.002)^{* * *}$ \\
7.Career choice - public accountant & $0.146(\mathrm{p}=0.053)^{*}$ & \\
8.Career choice - private accountant & $-0.329(\mathrm{p}=0.000)^{* * *}$ & \\
9.Career choice - other & & \\
\hline All
\end{tabular}

All correlations were based on Spearman's rho for non-parametric data

*correlation is significant at the 0.10 level (2-tailed)

$* *$ correlation is significant at the 0.05 level (2-tailed)

$* * *$ correlation is significant at the 0.01 level (2-tailed)

This study finds that more factors are significantly related to the decision to pursue professional accounting qualification than to decision to pursue accounting major. Eight of these factors were positively related to students' decisions to opt for an accounting degree and one factor, choosing other than accountant as a career choice was negatively related to students' decision to major in accounting. The most powerful motivating factor or influence was family members working as accountants and auditors. It is likely that these family members portray a positive image of accountants who have positively motivated these Gen Y

[Type here] 
students to study accounting in universities. This factor is related to perceived job-related factors like good working condition and job satisfaction which are suggested by existing studies such as Byrne, Willis and Burke (2012) as the most powerful motivating factor towards choosing accountant as a career. The second strong factor was a public accountant as a career choice, followed by students' level of keenness or eagerness for receiving information related to accounting major, professional accounting courses and from the experience-sharing session with experienced accounting educator and young qualified accounting professionals. Students with a reasonable prior interest in accounting and accounting profession are very excited to gather relevant information for a program such as KPP. The result in that support career talks and similar programs as a significant factor is consistent with Sugahara et al., (2009). However, exposure for a career talk and seminars, parents and school councillors were statistically significant but at lower significant levels.

There were only three factors which were significantly related to students' decision to pursue professional accounting courses. These factors were family members in the accounting profession, public accountant as a career choice and parents' influence. However, these factors were statistically significant at a higher level. Nevertheless, students' decision to major in accounting was significantly related to their decisions to pursue professional accounting courses as 119 of them have decided to enrol in accounting degree first.

\section{CONCLUSION AND RECOMMENDATIONS}

This study attempts to identify what factors motivate students to major in accounting and to take professional accounting courses. Data was collected via a questionnaire which was distributed to each participant of the KPP one-day program. The study finds that majority of the respondents were female and the majority of them intends to choose accounting as their major and greater numbers of respondents are interested in pursuing professional accounting qualification relative to an accounting degree.

Thirteen factors were extracted from the questionnaire and based on statistical analysis, seven factors were positively influencing students' decisions to major in accounting. Ranked in accordance to the statistical power, these factors are family members in the accounting profession, public accountant as a career choice, students' interest in receiving relevant information, choosing private accountants as a career, parents, school counsellor and career talk. Expectedly, one factor, choosing another profession as a career will have opposite effect on students' decision. Students whose ambitions are not related to accounting will not opt to study accounting.

Despite greater numbers of students decide to pursue professional accounting courses, this study only finds four significant motivating factors. These factors are a decision to major in accounting, family members in the accounting profession, public accountant as a career choice and parents. Students are more motivated by parents to take professional accounting courses as compared to enrol for accounting degree which may highlight the need for family moral support to ease the perceived difficulty related to professional accounting courses.

Since most of the KPP program contents focused on professionally qualified accountants, a higher number of students chose to do professional accounting courses relative to accounting degree showed that the KPP program had to a certain degree made a positive impact on students' inclination towards being professionally qualified accountants. Therefore, this study 
recommends other universities to organise similar programs to increase school students' awareness towards accounting courses and to choose qualified accountant as their desired career as well as to scout for quality potential accounting students and accounting professionals.

\section{REFERENCES}

Agarwala, T. (2008). Factors influencing career choice of management students in India. Career Development International, 13(4), 362-376.

Ahmed, K., Alam, K. F., \& Alam, M. (1997). An empirical study of factors affecting accounting students' career choice in New Zealand. Accounting Education, 6(4), 325335 .

Allen, C. L. (2004). Business students' perception of the image of accounting. Managerial Auditing Journal, 19(2), 235-258.

Blackwell, E. \& Pinder, P. J. (2013). What are the motivational factors of first-generation minority college students who overcome their family histories to pursue higher education?. STEM Education Research Institute (SERI), Indiana University, Purdue University.

Blackwell, E., \& Pinder, P. J. (2014). What are the motivational factors of first-generation minority college students who overcome their family histories to pursue higher education? College Student Journal, 48(1), 45-56.

Byrne, M., Willis, P., \& Burke, J. (2012). Influences on school leavers' career decisions Implications for the accounting profession. The International Journal of Management Education, 10(2), 101-111.

Carpenter, P. \& Foster, B. (1977). The career decisions of student teachers. Educational Research and Perspectives, 4(1), 23-33.

Cohen, J. \& Hanno, D. M. (1993). An analysis of underlying constructs affecting the choice of accounting as a major. Issues in Accounting Education, 8(2), 219-238.

Committee to Strengthen the Accountancy Profession (CSAP) (2014). Report on the strengthening of the accountancy profession in Malaysia.

Dalci, I., Arasli, H., Tumer, M., \& Baradani, S. (2013). Factors that influence Iranian students' decision to choose accounting major. Journal of Accounting in Emerging Economics, 3(2), 145-163.

Dalton, D. W., Buchheit, S. \& McMillan, J. J. (2014). Audit and tax career paths in public accounting: An analysis of student and professional perceptions. Accounting Horizons, 28(2), 213-231.

Felton, S., Buhr, N. \& Northey, M. (1994). Factors influencing the business student's choice of a career in chartered accountancy. Issues in Accounting Education, 9(1), 131-141.

[Type here] 
Felton, S., Dimnik, T. \& Northey, M. (1995). A Theory of reasoned action model of the chartered accountant career choice. Journal of Accounting Education, 13(1), 1-19.

Geiger, M. A. \& Ogilby, S. M. (2000). The first course in accounting students' perception and their effect on the decision to major in accounting. Journal of Accounting Education, 18(2), 63-78.

Gul, F. A., Andrew, B. H., Leong, S. C. \& Ismail, Z. (1989). Factors influencing the choice of the discipline of study-accountancy, engineering, law, and medicine. Accounting and Finance, 29(2), 93-101.

Hermanson, Dana, R., \& Hermanson, Roger, H. (1995) to confirm the name. Are America's top business students steering clear of accounting? Ohio CPA Journal, 54(2), 1-9.

Jackling, B. \& Calero, C. (2006). Influences on undergraduate students' intentions to become qualified accountants: Evidence from Australia. Accounting Education: An International Journal, 15(4), 419-438.

Jackman, S., \& Hollingworth, A. (2005). Factors influencing the career choice of accounting students: a New Zealand study. NZ Journal of Applied Business Research, 4(1), 69-84.

Law, P. K. (2010). A theory of reasoned action model of accounting students' career choice in public accounting practices in the post-Enron. Journal of Applied Accounting, 11(1), 5873.

Lowe, D. R. \& Simons, K. (1997). Factors influencing the choice of business major some additional evidence: A research note. Accounting Education, 6(1), 39-45.

Malaysian Institute of Accountant (MIA). (2015). Malaysian Institute of Accountants Annual Report 2015.

Malaysian Institute of Accountant (MIA). (2014). Malaysian Institute of Accountants Annual Report 2014.

Marriott, P., \& Marriott, N. (2003). Are we turning them on? A longitudinal study of undergraduate accounting students' attitude towards accounting as a profession. Accounting Education: An International Journal, 12(2), 113-133.

Maslow, a. H. (1943). A theory of human motivation. Psychological Review, 50(13), 370396.

Mauldin, S., Crain, J. L., \& Mounce, P. H. (2000). The accounting principles instructors' influence on students' decision to major in accounting. Journal of Education for Business, 75(3), 142-148.

Nelson, I. T., Vendrzyk, V. P., Quirin, J. J. \& Allen, R. D. (2002). No, the sky is not falling: Evidence of accounting student characteristics at FSA schools, 1995-2000. Issues in Accounting Education, 17(3), 269-287. 
Paolillo, J. \& Estes, R. (1982). An empirical analysis of career choice factors among accountants, attorneys, engineers, and physicians. The Accounting Review, 57(4), 785793.

Ryan, R. \& Deci, E. (2000). Intrinsic and extrinsic motivations: Classic definitions and new directions. Contemporary Educational Psychology, 25(1), 54-67.

Soni, G., \& Kodali, R. (2012). A critical review of empirical research methodology in supply chain management. Journal of Manufacturing Technology Management, 23(6), 753-779.

Sugahara, S. \& Boland, G. (2006). Perceptions of the certified public accountants by accounting and non-accounting tertiary students in Japan. Asian Review of Accounting, $14(1 / 2), 149-167$.

Sugahara, S., Hiramatsu, K. \& Boland, G. (2009). The factors influencing accounting school students' career intention to become a Certified Public Accountant in Japan. Asian Review of Accounting, 17(1), 5-22.

Smyth, E., \& Hannan, C. (2000). Spoilt for choice? School factors and third-level entry. Seminar paper. Dublin: The Economic and Social Research Institute.

Tan, L. M. \& Laswad, F. (2006). Students' beliefs, attitudes and intentions to major in accounting. Accounting Education, 15(2), 167-187.

Ulmer, J. T., \& Wilson, M. S. (2003). The potential contributions of quantitative research to symbolic interactionism. Symbolic Interaction, 26(4), 531-552.

Wilder, M. \& Stocks, M. H. (2004). Are accounting graduates favourably recruited for entrylevel management positions? Management Accounting Quarterly, 5(3), 21-28.

Zyl, C. V. \& Villiers, C. D. (2011). Why some students choose to become chartered accountants (and others do not). Meditari Accountancy Research, 19(1/2), 56-74. 